\title{
KINERJA DAN ANALISIS FINANSIAL BUDIDAYA UDANG VANAME (Litopenaeus vannameI) DI PT. NOERWY AQUA FARM KAB. SUKABUMI PROV. JAWA BARAT
}

\section{VANAME SHRIMP CULTIVATION PERFORMANCE AND ANALYSIS (Litopenaeus vannamei) AT PT. NOERWY AQUA FARM SUKABUMI DISTRICT, WEST JAVA PROVINCE}

\author{
Eka Desri Kayandi\#, Effi Athfiyani Thaib, Iin Siti Djunaidah, dan Basuki Rachmad \\ Politeknik Ahli Usaha Perikanan \\ Jl. AUP Pasar Minggu, Jakarta Selatan \\ E-mail: ekadesrikayandii@gmail.com
}

(Diterima: 13 Oktober 2020; Diterima setelah perbaikan: 29 Desember 2020; Disetujui: 29 Desember 2020)

\begin{abstract}
ABSTRAK
Tujuan penelitian ini untuk menganalisis kinerja budidaya udang vaname dan menghitung analisis finansial usaha budidaya udang vaname. Penelitian dilakukan mulai dari tanggal 02 Maret 2020 sampai 15 Mei 2020 di PT. Noerwy Aqua Farm yang berada di Desa Cipeundeuy, Kecamatan Surade, Kabupaten Sukabumi, Provinsi Jawa Barat. Metode penelitian yang dilakukan adalah metode observasi dengan pola magang. Tujuh petak tambak dipergunakan dan pemeliharaan secara intensif dengan padat tebar $184 \mathrm{ekor} / \mathrm{m}^{2}$. Kinerja budidaya yang diperoleh selama penelitian yaitu Average Daily Growth 0,17 gram/hari sampai 0,72 gram/hari, Survival Rate 72-83\%, efektivitas penggunaan pakan dihitung dengan nilai Feed Conversion Ratio 1,1-1,5 dan produktivitas antara 32,09-38,19 ton/ha. Hasil produksi selama penelitian menghasilkan keuntungan sebesar Rp.7.892.873.428 pertahun dengan Revenue Cost Ratio 1,86, Break Even Point sebesar Rp.3.976.500.424 dan Payback Period selama 2,41 tahun. Kinerja budidaya yang dihasilkan dapat dikatakan baik dan berdasarkan analisis finansial usaha budidaya layak untuk dilakukan.
\end{abstract}

KATA KUNCI: Analisis finansial; Budidaya Udang vaname; kinerja budidaya

\begin{abstract}
This research aimed to analyse vaname shrimp aquaculture performance productivity and to calculate financial aspect for business of vaname shrimp cultivation. Research conducted during period of 02 March 2020 until 15 Mei 2020 at PT. Noerwy Aqua Farm located in Desa Cipeundeuy, Kecamatan Surade, Kabupaten Sukabumi, West Java. Research method is by observation during apprenticeship. Seven pond blocks were employed and maintained intensively with spread density of $184 \mathrm{shrimp}$ fry/m $\mathrm{m}^{2}$. aquaculture performance productivity gained from the research are as follows: Average Daily Growth 0,17 grams/day up until 0,72 grams/day, Survival Rate 72-83\%, feeding effectivity of Feed Conversion Ratio 1,1-1,5 with productivity ranges between 32,09-38,19 ton/ha. Production revenue gained during research period is Rp.7.892.873.428 yearly with Revenue Cost Ratio 1,86, Break Even Point as much as Rp.3.976.500.424 and Payback Period for 2.41 years. Aquaculture performance productivity obtained considerably good and through financial analysis cultivation business is feasible by all means.
\end{abstract}

KATA KUNCI: Financial Analysis; Vaname shrimp; aquaculture performance productivity

\section{PENDAHULUAN}

Udang vaname (Litopenaeus vannamer) merupakan salah satu komoditas pangan perikanan unggulan di pasar global dan domestik yang memiliki nilai

\# Korespondensi: Politeknik Ahli Usaha Perikanan

E-mail: ekadesrikayandii@gmail.com ekonomis tinggi (Afan et al., 2015; Dahlan et al., 2019; Isamu et al., 2018). Target produksi udang pada tahun 2020 ditingkatkan untuk mencukupi kebutuhan tersebut menjadi menjadi sebanyak 650.000 ton (DJPS, 2020). 
Peningkatan budidaya udang secara intensif menimbulkan resiko terjangkit penyakit yang lebih tinggi (Umiliana et al., 2016) dan mortalitas yang meningkat sejalan dengan penurunan kualitas air semasa pemeliharaan. Udang vaname yang dikenal unggul dari udang yang lain, ternyata dapat terserang WSSV (Arafani et al., 2016). Infeksi bakteri juga menyerang udang vaname, bakteri dapat mengakibatkan kematian masal pada budidaya udang vaname, bakteri yang dapat mengakibatkan kematian pada udang vaname adalah bakteri genus Vibrio (Kharisma \& Abdul, 2012).

PT. Noerwy Aqua Farm merupakan salah satu perusahaan yang bergerak di bidang produksi udang vaname yang terletak di Kabupaten Sukabumi, Provinsi Jawa Barat. Berdasarkan latar belakang tersebut, diperlukan analisis kinerja budidaya dan analisis finansial budidaya udang vaname untuk mengetahui baik atau tidaknya hasil produksi serta mengetahui kelayakan usaha dari budidaya yang dilakukan.

Tujuan dari penelitian ini adalah, untuk mengetahui kinerja budidaya pada PT. Noerwy Aqua Farm yang meliputi : Produktivitas, Average Daily Growth (ADG), Survival Rate (SR), dan Feed Convertion Ratio (FCR) serta analisis finansial pembesaran udang vaname meliputi biaya investasi, biaya operasional, laba/rugi, Benefit Cost Ratio (B/C Ratio), Break Even Point (BEP), Payback Period (PP), dan Return on Investment (ROI).

\section{BAHAN DAN METODE}

Penelitian dilakukan selama 90 hari pada 7 (tujuh) petakan tambak. Sampling pertumbuhan udang pertama kali dilakukan pada DOC 30 dan pengamatan selanjutnya dilakukan selang sepuluh hari sampai panen pada DOC 90. Penelitian ini dilakukan mengikuti kaedah-kaedah penelitian yang bertujuan mengumpulkan dan menganalisis data yang dideskripsikan dalam bentuk tulisan. Segala kegiatan pengumpulan data diperoleh dari narasumber yang dipercaya yaitu dari semua pihak terkait yang berada di PT. Noerwy Aqua Farm.

Penelitian dilakukan di PT. Noerwy Aqua Farm yang beralamat di Desa Cipeundeuy, Kecamatan Surade, Kabupaten Sukabumi, Provinsi Jawa Barat pada bulan Maret sampai Mei 2020. Data primer diperoleh melalui pengambilan langsung di lapangan berupa berat udang setiap waktu sampling, kelangsungan hidup dan jumlah pakan yang dihabiskan selama penelitian dan wawancara kepada semua pihak yang terkait di PT. Noerwy Aqua Farm. Pada penelitian ini data sekunder diperoleh dari instasi pemerintah, logbook perusahaan, buku acuan, jurnal - jurnal ilmiah, surat kabar, instansi swasta, dan data-data lain yang mendukung.

Data yang dikumpulkan meliputi sarana dan prasarana yang dimiliki, alat dan bahan yang digunakan, metode yang dijalankan, serta data panen termasuk data 5 (lima) siklus pemeliharaan yang berlangsung sebelum penelitian dilakukan. Kinerja budidaya yang diamati meliputi pertumbuhan berat mutlak, rata-rata pertumbuhan harian (Average Daily Growth), produktivitas, survival rate (SR), dan feed conversion ratio (FCR). Sedangkan analisis finansial yang diamati yaitu Laba/Rugi, Revenue Cost Ratio (R/C Ratio), Break Even Point (BEP), dan Payback Period (PP). Parameter kinerja budidaya dan analisis finansial pada penelitian ini didapatkan dengan mempergunakan perhitungan sesuai literatur yang diunduh.

\section{Kinerja Budidaya}

Kinerja budidaya yang diamati pada penelitian ini berupa, Produktivitas, Average Body Weight (ABW), Average Daily Growth (ADG), Survival Rate (SR) dan Feed Conversion Ratio (FCR), diperoleh dengan menggunakan rumus. Kinerja budidaya diperoleh dengan menghitung produktivitas yang menggunakan rumus berdasarkan standar operasional yang ada di perusahaan sebagai berikut:

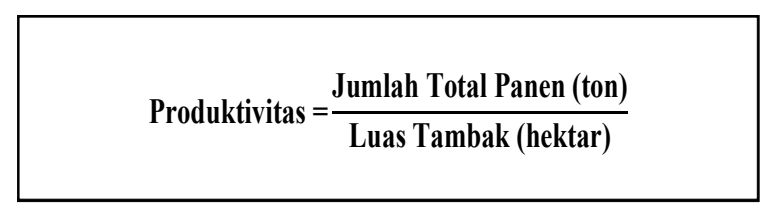

Perhitungan Berat Rata-Rata atau Average Body Weight (ABW), dipergunakan untuk mengukur kinerja budidaya. Menurut Amri dan Kanna (2008), perhitungan $\mathrm{ABW}$ dilakukan dengan rumus berikut:

$$
\mathrm{ABW}=\frac{\text { Berat total udang yang tertangkap (gram) }}{\text { Jumlah udang yang tertangkap (ekor) }}
$$

Average Daily Growth (ADG), menurut Haliman dan Adijaya (2008), ADG dapat dihitung dengan rumus:

$$
\mathrm{ADG}=\frac{\mathrm{ABWt}(\text { gram} / \mathrm{ekor})-\mathrm{ABW} \text { (gram/ekor) }}{\mathrm{T}(\text { hari })}
$$

Keterangan :

$\mathrm{ABW}_{0}=$ Berat rata-rata awal per individu udang (g/ekor)

$\mathrm{ABW}_{\mathrm{t}}=$ Berat rata-rata akhir per individu udang (g/ekor)

$\mathrm{T} \quad=$ Waktu (hari) 
Survival Rate (SR), menjadi hal yang penting dalam mengukur kinerja budidaya. Menurut Haliman dan Adijaya (2008), SR dapat dihitung menggunakan rumus :

$$
\mathrm{SR}=\frac{\text { Jumlah udang yang dipanen (ekor) }}{\text { Jumlah benur yang ditebar (ekor) }} \times 100 \%
$$

Kinerja Budidaya dapat dinilai berdasarkan Feed Conversion Ratio (FCR). Menurut Sawhney dan Roopma (2010) FCR dapat dihitung dengan rumus:

$$
\mathrm{FCR}=\frac{\text { Total pakan yang diberikan }(\mathrm{kg})}{\text { Pertambahan berat }(\mathrm{kg})}
$$

\section{Analisis Finansial}

Analisis Finansial dapat dilakukan dengan berbagai cara di antaranya menghitung Laba Rugi, Revenue Cost Ratio (R/C Ratio), Break Even Point (BEP) dan Payback Period (PP).

Menurut Isamu et al., (2018) pendapatan usaha dalam budidaya udang vanamei menggunakan persamaan sebagai berikut:

\section{Laba/Rugi $=$ TR - TC}

Keterangan:

$\mathrm{TR}=$ Total revenue (penerimaan total)

$\mathrm{TC}=$ Total cost (biaya total)

Menurut Umar (2005), Revenue Cost Ratio (R/C ) dapat dihitung berdasarkan rumus berikut:

$$
\mathbf{R} / \mathbf{C} \text { Ratio }=\frac{\text { TR }}{\mathbf{T C}}
$$

Keterangan :

$T R=$ Total revenue/total penerimaan

$\mathrm{TC}=$ Total cost/total biaya

Break Even Point (BEP), menurut Sumardika (2013), Break Even Point dapat dihitung berdasarkan rumus berikut:

$$
\text { BEP }(\text { Harga })=\frac{\text { Biaya Tetap }(\mathrm{Rp})}{1-\frac{\text { Biaya Variabel }(\mathrm{Rp})}{\text { Total Penjualan }(\mathrm{Rp})}}
$$

Payback Period (PP), menurut Kasmir dan Jakfar (2009), Payback Period dapat dihitung berdasarkan rumus berikut :

$$
\text { PP }(\text { tahun })=\frac{\text { Nilai Investasi }(\text { Rp })}{\text { Laba bersih }+ \text { Penyusutan }} \times 1 \text { tahun }
$$

\section{Analisis Data}

Analisis data dilakukan dengan metode deskriptif yaitu dengan menjelaskan hal-hal yang dilakukan dan diamati selama penelitian sesuai dengan batasan masalah kemudian membandingkan hasil yang diperoleh dengan literatur yang sesuai.

\section{HASIL DAN PEMBAHASAN}

\section{Kinerja Budidaya}

Kinerja budidaya di PT. Noerwy Aqua Farm secara umum sudah mencapai target produksi perusahaan (Tabel 1)

\section{Pertumbuhan}

Pertumbuhan berat mutlak dilakukan untuk mengetahui pertumbuhan berat rata-rata udang setiap sampling dilakukan. Berat rata-rata udang vaname paling baik terjadi pada petak pemeliharaan E3. Berat rata-rata udang terus meningkat seiring berjalannya masa pemeliharaan (Gambar 1). Hal ini sesuai dengan pendapat Witoko et al. (2018) bahwa udang vaname meningkat bersamaan dengan waktu pemeliharaan.

Pertumbuhan rata-rata harian udang vaname berkisar antara 0,17 gram/hari sampai 0,72 gram/hari. Pertumbuhan paling baik rata-rata dari 7 kolam pengamatan dilihat dari grafik tersebut terjadi pada umur 60-70 hari, sementara grafik laju pertumbuhan harian dapat dilihat pada Gambar 2.

Dari Gambar 2 dapat dilihat bahwa rata-rata pertumbuhan harian udang pada semua kolam pengamatan dapat dikatakan baik karena nilai yang diperoleh berada melebihi standar, di mana menurut SNI 01-7246 (2006) rata-rata pertumbuhan harian pembesaran udang vaname yaitu 0,2 gram/hari.

\section{Survival Rate}

Survival rate pada saat pengamatan berkisar antara $72 \%-83 \%$. Pencapaian SR pada 5 siklus terakhir dapat dilihat pada Gambar 3.

Dari Gambar 3 dapat dilihat bahwa SR udang vaname selama 5 siklus terakhir mengalami peningkatan dan penurunan. SR pada siklus ke 5 dapat dikatakan paling baik karena beberapa petak mampu mencapai target perusahaan bahkan ada yang mencapai 
Tabel 1. Target Produksi

Table 1. Production Target

\begin{tabular}{clrrr}
\hline No & \multicolumn{1}{c}{ Variabel } & Target & Standar & Hasil \\
\hline 1 & $\begin{array}{l}\text { Masa Pemeliharaan } \\
\text { (hari) }\end{array}$ & 90 & $90-120$ & 90 \\
2 & $\begin{array}{l}\text { Padat Tebar } \\
\left(\text { Ekor } / \mathrm{m}^{2}\right)\end{array}$ & 150 & $80-20$ & $181-184$ \\
3 & $\begin{array}{l}\text { Size Panen } \\
(\text { Ekor/kg) }\end{array}$ & 50 & $50-66$ & $31-38$ \\
4 & SR Minimal (\%) & 75 & 80 & $72-83$ \\
5 & FCR & 1,5 & 1,5 & $1,1-1,5$ \\
6 & $\begin{array}{l}\text { Produktivitas } \\
\text { (ton/ha) }\end{array}$ & 22,5 & 20,25 & $32,09-38,19$ \\
\hline
\end{tabular}

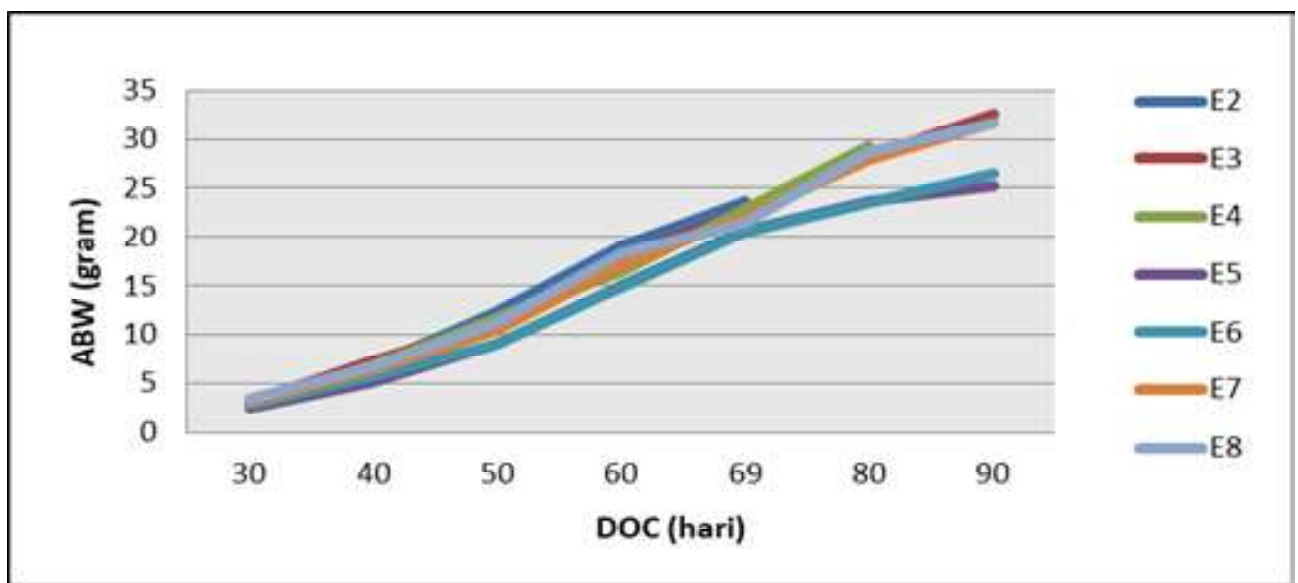

Gambar 1. Pertumbuhan Berat Mutlak.

Figure 1. Absolute Weight Growth.

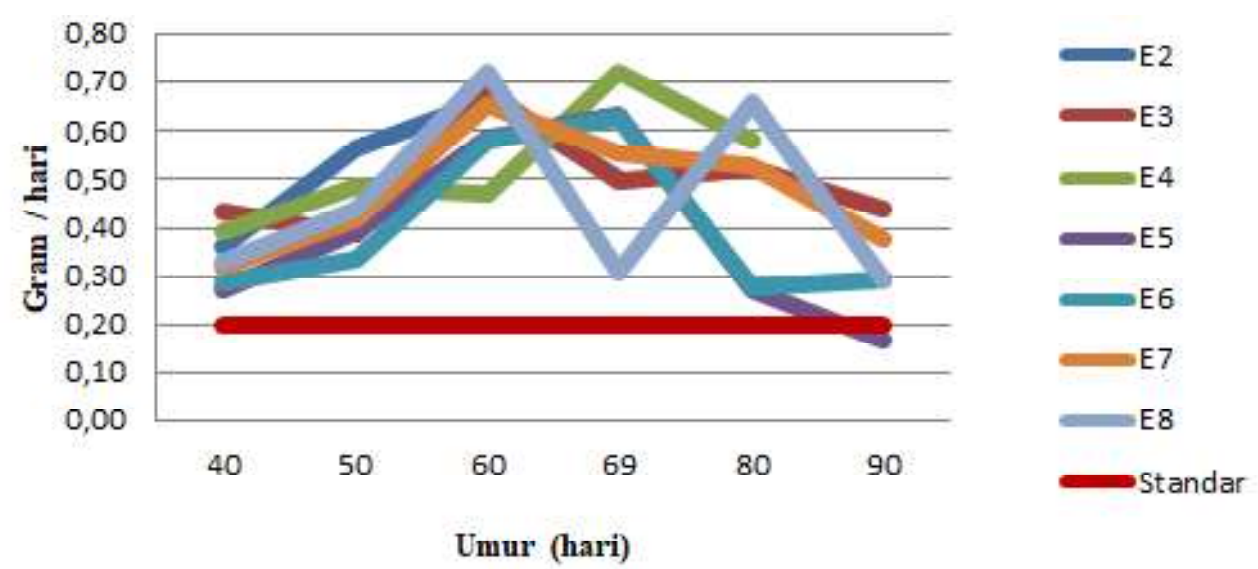

Gambar 2. Pertumbuhan harian rata-rata.

Figure 2. Average Daily Growth.

standar SNI 8008 (2014) yaitu kolam E5 sebesar 83\% dan beberapa petak lainnya tidak begitu jauh dari target. Berbeda dengan siklus sebelumnya yang bisa dikatakan jauh dari nilai target yang direncanakan perusahaan. SR di lokasi pengamatan pada siklus ke 5 atau pada saat penelitian yaitu E2 72\%, E3 75\%, E4
78\%, E5 76\%, E6 73\%, E7 83\%, dan E8 75\%. Hal ini dapat dikatakan baik karena SR yang diperoleh di atas standar SNI 8008 (2014) di mana menurut Arsad et al. (2017) bahwa SR udang vaname yaitu 70\%. Sementara menurut Fuady et al., (2013) SR pembesaran udang yaitu $75 \%$. 


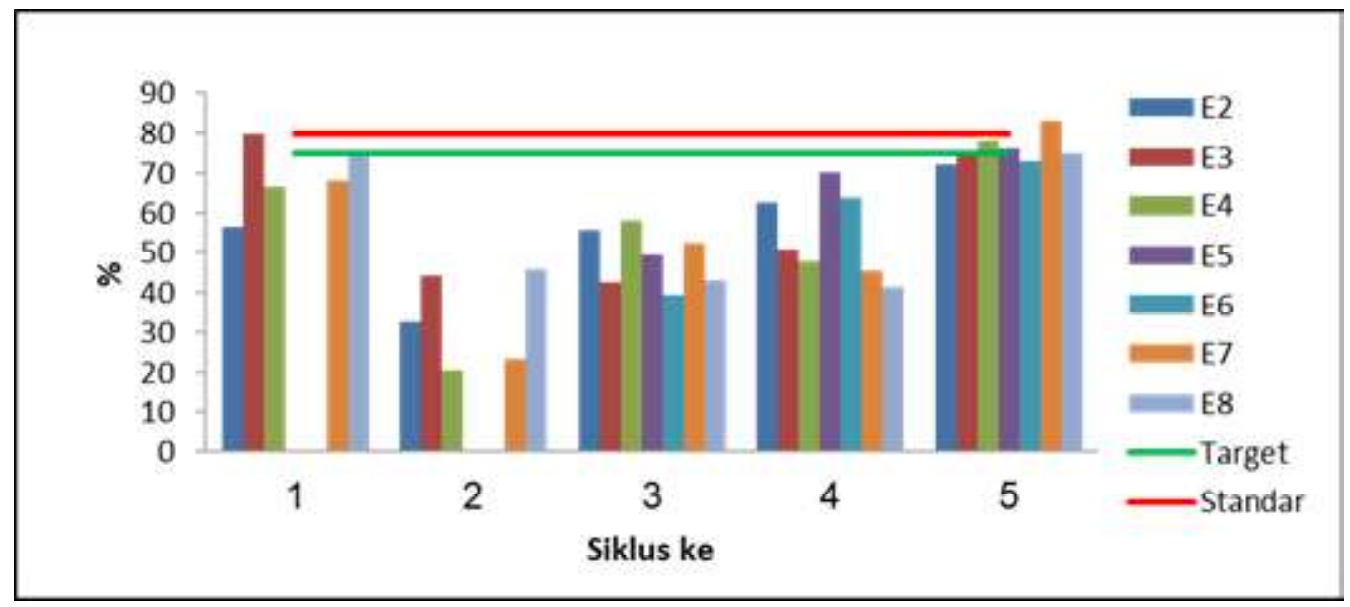

Gambar 3. Tingkat Kelangsungan Hidup.

Figure 3. Survival Rate.

\section{Feed Conversion Ratio}

Nilai FCR pada saat pengamatan tidak melebihi target maupun standar. Hal ini dapat dikatakan baik karena semakin kecil nilai FCR maka semakin baik. Hal ini dapat dilihat pada Gambar 4.

Nilai FCR paling baik yaitu kolam E2 dengan nilai 1,1 sementara nilai tertinggi yaitu kolam E6 dengan nilai 1,5 . Artinya untuk menghasilkan udang seberat $1 \mathrm{~kg}$ membutuhkan pakan sebanyak $1,1 \mathrm{~kg}$ sampai 1,5 kg. Perusahaan menargetkan FCR di bawah 1,5. Sementara menurut SNI 01-7246 (2006) FCR untuk pembesaran udang vaname yaitu 1,5. Sementara menurut Arsad et al. (2017), menyatakan bahwa FCR pembesaran udang vaname yaitu $1,4-1,8$.

\section{Produktivitas}

Produktivitas tambak di PT. Noerwy Aqua Farm unit Surade yaitu 32,09 ton/ha sampai 38,19 ton/ha. Hal ini sangat baik karena mampu melebihi target yang direncanakan oleh perusahaan dan mampu melebihi standar. Perusahaan sendiri menargetkan produktivitas sebesar 22,5 ton/ha. sementara grafik produktivitas tambak selama 5 siklus terakhir dapat dilihat pada Gambar 5.

Berdasarkan Gambar 5 dapat dilihat bahwa produktivitas tambak di lokasi selama 5 siklus terakhir mengalami peningkatan dan penurunan pada setiap siklusnya. Siklus terakhir merupakan siklus dengan produktivitas paling baik di mana mampu melebihi target dan standar di mana perusahaan menargetkan 22,5 ton/ha sementara standar menurut SNI 8008 (2014) yaitu 20 ton/ha. Arifin et al. (2018) menambahkan bahwa produktivitas tambak pada pembesaran udang vaname yaitu 22-23 ton/ha. Sementara pada siklus-siklus sebelumnya hanya ada satu tambak yang mampu mencapai standar dan target yaitu petak E6 pada siklus ke 4.

\section{Kualitas Air}

Pengelolaan kualitas air menjadi salah satu indikator kestabilan kondisi tambak dan berdampak pada tingkat kelangsungan hidup biota yang dipelihara

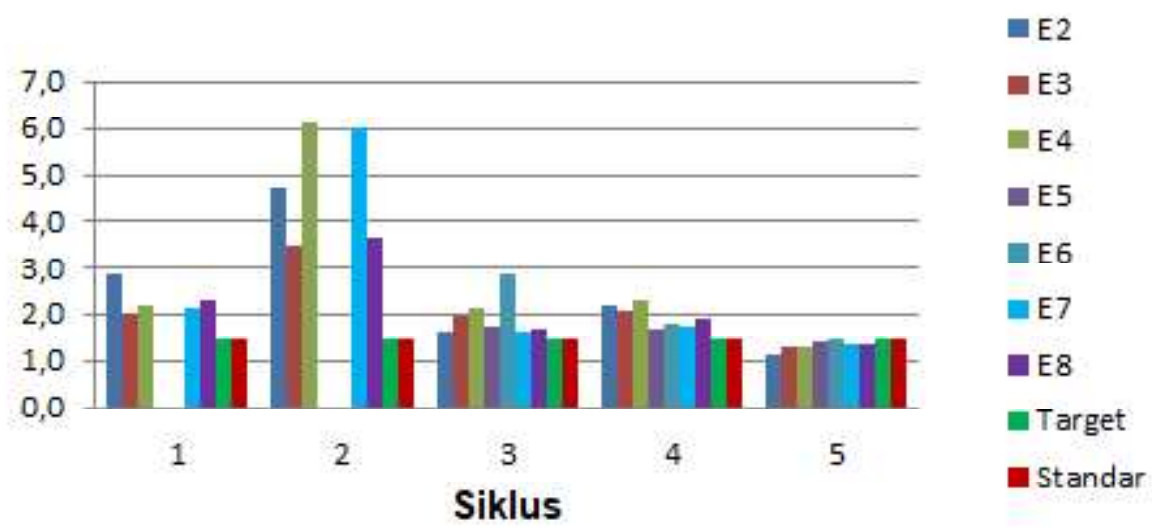

Gambar 4. Rasio Konversi Pakan.

Figure 4. Feed Conversion Ratio. 


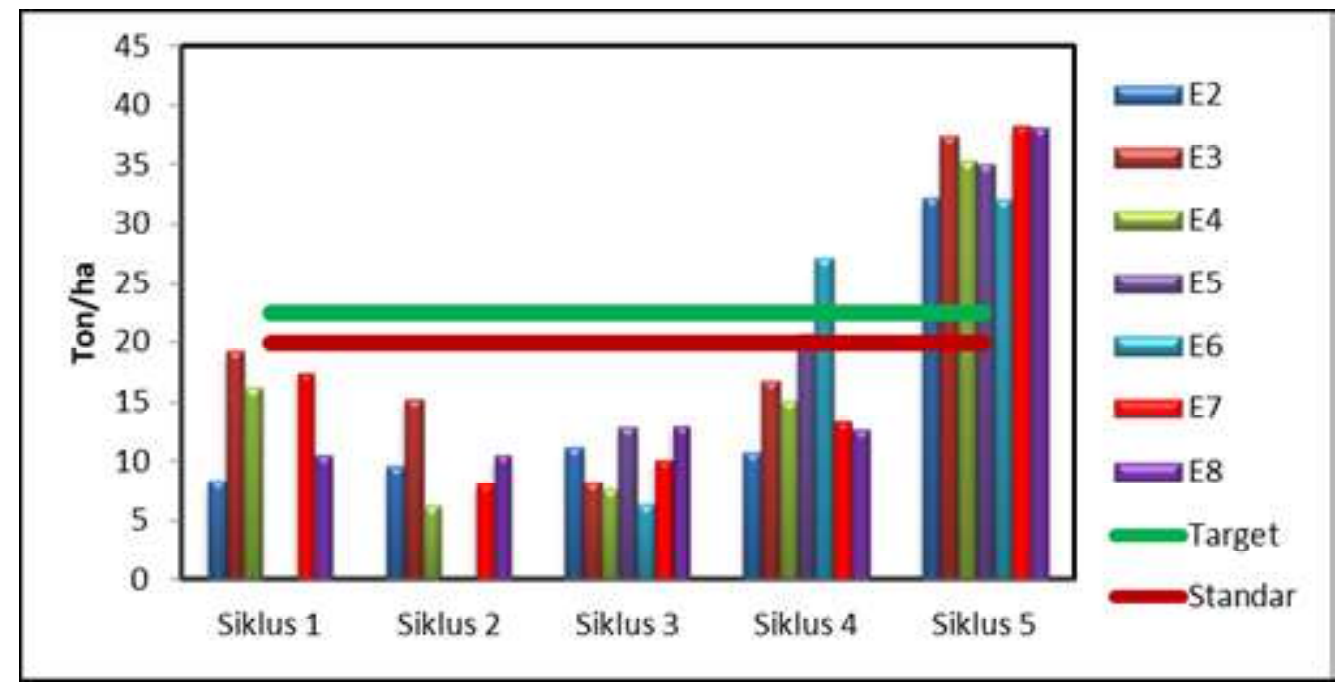

Gambar 5. Produktivitas.

Figure 5. Productivity.

(Romadhona et al., 2016). Pengelolaan air dilakukan untuk memastikan air media pemeliharaan agar tetap berada pada kondisi optimal, serta dilakukan dengan baik dan benar sehingga produktivitas tinggi (Choeronawati et al., 2019).

Kualitas air mempunyai peranan penting sebagai pendukung terhadap kelangsungan hidup dan pertumbuhan udang vaname. Parameter fisika adalah salah satu parameter yang digunakan untuk mengukur kadar kualitas air yang berhubungan dengan fisika seperti kecerahan, suhu, dan salinitas. Sementara parameter kimia meliputi kelarutan oksigen, $\mathrm{pH}$, amoniak, nitrit, dan alkalitinas (Elfidiah, 2016).

Hasil pengamatan kualitas air di PT. Noerwy Aqua Farm belum optimal di mana terdapat beberapa parameter yang tidak sesuai dengan standar. Hal ini disebabkan karena padat tebar yang tinggi serta belum optimalnya pengelolaan kualitas air yang dilakukan. Hal ini dapat dilihat pada Tabel 2.

\section{Analisis Finansial}

Panen di lokasi terdiri dari panen parsial dan panen total. Panen parsial dilakukan dengan tujuan untuk mengurangi populasi udang ketika carying capacity sudah tercapai. Sehingga setelah panen parsial dilakukan diharapkan dengan menurunnya kepadatan, pertumbuhan udang bisa meningkat kembali. Hal ini sependapat dengan Purnamasari et al. (2017) yang menyatakan panen parsial yaitu panen sebagian untuk mengurangi kepadatan udang di tambak. Panen parsial dilakukan 3 kali yaitu pada umur pemeliharaan 62 hari, 71 hari, dan 83 hari. Panen total dilakukan ketika target size atau target waktu pemeliharaan sudah tercapai. Harga udang dipengaruhi oleh size, kualitas serta keadaan pasar. Penyortiran udang dilakukan menjadi
3 kualitas, yaitu FQ (First Quality), SQ (Second Quality), dan BS (Below Standard). Udang dengan kualitas FQ dijual dengan harga yang sesuai, dengan kualitas SQ dijual dengan harga 40\% dari harga FQ.

Pemasaran hasil panen dilakukan dengan cara lelang kepada buyer-buyer yang telah bekerjasama dan dengan harga yang telah disepakati. Penentuan buyer dilakukan oleh manager dengan berbagai pertimbangan. Buyer akan datang ke lokasi pada saat panen dan melakukan penyortiran. Analisis finansial budidaya udang vaname dapat dilihat padaTabel 3 .

Investasi adalah modal awal yang dikeluarkan untuk mendirikan dan menjalankan usaha produksi udang vaname atau komitmen sejumlah dana atau sumber daya lainnya yang dilakukan pada saat ini, dengan tujuan memperoleh sejumlah keuntungan di masa datang dengan waktu yang relatif lama (Ustiani, 2015; Ulumiah et al., 2020). Nilai penyusutan sendiri diperoleh dari biaya produksi dibagi umur ekonomis.

Biaya tetap (fixed $\cos t)$ adalah biaya yang relatif tetap jumlahnya dan terus dikeluarkan walaupun produksi yang diperoleh banyak atau sedikit (Isamu et al., 2018). Besarnya biaya tetap tidak dipengaruhi oleh jumlah produksi pada saat itu. Biaya tidak tetap (variable cost) merupakan biaya yang habis terpakai dalam satu kali periode produksi (Pulungan et al., 2015). Besar kecilnya biaya tidak tetap dipengaruhi oleh banyaknya jumlah produksi usaha budidaya udang vaname, atau biaya yang dikeluarkan selama proses produksi berlangsung dan berubah-ubah sesuai dengan jumlah produksinya (Isamu et al., 2018).

Pendapatan (income) merupakan total penjualan dari hasil panen udang selama satu tahun atau satu siklus pemeliharaan. Setiap pengusaha akan berusaha 
Tabel 2. Nilai Kisaran Parameter Kualitas Air

Table 2. Water Quality Parameter Range Values

\begin{tabular}{|c|c|c|c|c|c|c|c|c|c|}
\hline \multirow[t]{2}{*}{ Parameter } & \multicolumn{7}{|c|}{ Petak } & \multirow[t]{2}{*}{ Standar } & \multirow[t]{2}{*}{ Ket } \\
\hline & E2 & E3 & E4 & E5 & E6 & E7 & $\overline{\mathrm{E} 8}$ & & \\
\hline \multicolumn{10}{|l|}{$\begin{array}{l}\text { Suhu } \\
\left({ }^{\circ} \mathrm{C}\right)\end{array}$} \\
\hline 05.00 & 28,8 & 28,5 & 28,7 & 28,4 & 28,4 & 28,4 & 28,4 & \multirow{3}{*}{$\begin{array}{l}27- \\
33\end{array}$} & \multirow[t]{2}{*}{ Sesuai } \\
\hline 17.00 & 30,1 & 30,2 & 30,7 & 29,8 & 29,7 & 30,4 & 29,9 & & \\
\hline \multicolumn{9}{|l|}{$\begin{array}{c}\mathrm{DO} \\
(\mathrm{mg} / \mathrm{L})\end{array}$} & \\
\hline 05.00 & 3,81 & 3,88 & 3,93 & 3,92 & 3,9 & 4 & 3,8 & \multirow{3}{*}{$\begin{array}{c}\text { Min. } \\
4\end{array}$} & \multirow[t]{2}{*}{ Sesuai } \\
\hline 17.00 & 5,65 & 6,11 & 5,67 & 4,5 & 5,05 & 6,25 & 5,1 & & \\
\hline \multicolumn{9}{|l|}{$\mathrm{pH}(\mathrm{mg} / \mathrm{L})$} & \\
\hline 05.00 & 7,6 & 7,5 & 7,6 & 7,5 & 7,6 & 7,6 & 7,7 & \multirow{3}{*}{$\begin{array}{l}7,5- \\
8,5\end{array}$} & \multirow[t]{2}{*}{ Sesuai } \\
\hline 17.00 & 7,85 & 7,78 & 7,8 & 7,7 & 7,85 & 7,8 & 7,75 & & \\
\hline \multicolumn{9}{|l|}{$\begin{array}{l}\text { Salinitas } \\
(\mathrm{mg} / \mathrm{L})\end{array}$} & \\
\hline 05.00 & $\begin{array}{l}20- \\
27\end{array}$ & $20-30$ & $22-29$ & $21-30$ & $\begin{array}{c}23- \\
30\end{array}$ & $\begin{array}{c}22- \\
31\end{array}$ & $20-30$ & \multirow[t]{2}{*}{$\begin{array}{l}10- \\
32\end{array}$} & \multirow[t]{2}{*}{ Sesuai } \\
\hline 17.00 & $\begin{array}{l}20- \\
29\end{array}$ & $20-32$ & $23-30$ & $22-33$ & $\begin{array}{l}23- \\
33\end{array}$ & $\begin{array}{l}23- \\
33\end{array}$ & $20-33$ & & \\
\hline $\begin{array}{l}\text { Kecerahan } \\
(\mathrm{cm})\end{array}$ & $\begin{array}{l}20- \\
35\end{array}$ & $10-35$ & $10-45$ & $20-50$ & $\begin{array}{l}15- \\
40\end{array}$ & $\begin{array}{l}20- \\
35\end{array}$ & $15-35$ & $\begin{array}{l}30- \\
50\end{array}$ & $\begin{array}{l}\text { Tidak } \\
\text { sesuai }\end{array}$ \\
\hline $\begin{array}{l}\text { Alkalinitas } \\
\text { (gram/L) }\end{array}$ & $\begin{array}{l}190-1 \\
240\end{array}$ & $175-245$ & $195-280$ & $170-300$ & $\begin{array}{l}170- \\
280\end{array}$ & $\begin{array}{c}205- \\
300\end{array}$ & $220-315$ & $100-150$ & $\begin{array}{l}\text { Tidak } \\
\text { sesuai }\end{array}$ \\
\hline $\begin{array}{l}\text { Amoniak } \\
(\mathrm{mg} / \mathrm{L})\end{array}$ & $\begin{array}{c}2,4- \\
6\end{array}$ & $2,6-12$ & $0,8-5,2$ & $9-12$ & $9-15$ & $9-15$ & $8-12$ & $\begin{array}{c}\text { Mak. } \\
0,1\end{array}$ & $\begin{array}{l}\text { Tidak } \\
\text { Sesuai }\end{array}$ \\
\hline $\begin{array}{l}\text { Nitrit } \\
(\mathrm{mg} / \mathrm{L})\end{array}$ & $\begin{array}{c}0,6- \\
1,6\end{array}$ & $0,1-1,1$ & $0,7-1,6$ & $0,2-0,5$ & $0,4-0,8$ & $\begin{array}{c}0,3- \\
0,8\end{array}$ & $0,3-0,9$ & $\begin{array}{c}\text { Mak. } \\
1\end{array}$ & Sesuai \\
\hline
\end{tabular}

Tabel 3. Analisis Finansial Budidaya Udang Vaname

Table 3. Financial Analysis of Vaname Shrimp Cultivation

\begin{tabular}{clr}
\hline No & \multicolumn{1}{c}{ Uraian } & Nilai (Rp) \\
\hline 1 & Investasi & $22.979 .501 .000,-$ \\
2 & Penyusutan & $1.629 .189 .700,-$ \\
3 & Biaya Tetap & $2.401 .995 .700,-$ \\
4 & Biaya Tidak Tetap & $6.748 .271 .896,-$ \\
5 & Pendapatan per tahun & $17.043 .141 .024,-$ \\
6 & Laba/Rugi & $7.892 .873 .428,-$ \\
7 & R/C Ratio & 1,86 \\
8 & BEP harga & $3.976 .500 .424,-$ \\
9 & Payback Period (tahun) & 2,41 \\
\hline
\end{tabular}

memperoleh pendapatan pengelola yang setinggitingginya, karena pendapatan pengelola yang tinggi mencerminkan usaha memperoleh laba yang tinggi (Aulia, 2018).

Laba/rugi adalah selisih antara pendapatan total dan biaya total, adapun analisis laba/rugi ini bertujuan untuk mengetahui keberhasilan budidaya dari segi ekonomi, dengan ketentuan apabila selisih dari pendapatan dan biaya total menunjukkan nilai positif berarti mendapatkan laba, begitupun sebaliknya apabila menunjukkan nilai negatif berarti rugi (Aulia, 2018 ; Umar, 2005).

$\mathrm{R} / \mathrm{C}$ Ratio merupakan alat analisis untuk melihat keuntungan relatif suatu usaha dalam satu tahun terhadap biaya yang dipakai dalam kegiatan tersebut. Suatu usaha dikatakan layak bila R/C lebih besar dari 1 $(\mathrm{R} / \mathrm{C}>1$ ) (Primyastanto, 2011). Jika $\mathrm{R} / \mathrm{C}$ ratio semakin besar, usaha yang dijalankan mengalami keuntungan. Sebaliknya, jika $\mathrm{R} / \mathrm{C}$ ratio semakin kecil maka usaha tersebut mengalami kerugian. Jika $\mathrm{R} / \mathrm{C}$ ratio mengalami 
titik impas maka usaha yang dijalankan tidak mengalami kerugian dan keuntungan (Ulumiah et al., 2020).

Break Even Point atau titik impas merupakan keadaan di mana suatu usaha berada pada posisi tidak memperoleh keuntungan dan tidak megalami kerugian. BEP merupakan teknik analisis yang mempelajari hubungan antara biaya tetap, biaya variabel, volume kegiatan dan keuntungan (Primyastanto, 2011).

Payback periode merupakan metode yang mencoba mengukur seberapa cepat investasi bisa kembali. Karena itu satuan hasilnya bukan persentase, tetapi satuan waktu (bulan, tahun dan sebagainya). Kalau payback periode ini lebih pendek dari pada yang disyaratkan, maka proyek dikatakan menguntungkan, sedangkan kalau lebih lama proyek ditolak (Primyastanto, 2011).

\section{KESIMPULAN}

Kinerja budidaya pada saat pengamatan dapat dikatakan baik dan secara umum mempu mencapai target dan lebih baik dari 4 siklus sebelumnya. Berdasarkan analisis finansial, usaha budidaya udang yang dilakukan layak untuk dilanjutkan.

\section{DAFTAR PUSTAKA}

Afan, N., Tofik, H., \& Eko, B. (2015). Analisa Kelayakan Usaha Budidaya Udang Vaname (Litopaneaus vannameı) Pada Tambak Intensif. 11 (2): 25-31.

Arifin, N, Bai., Muhammad, F., Ating, Y., \& Anik, M, H. (2018). Komunitas Fitoplankton Pada Sistem Budidaya Intensif Udang Vaname, Litopenaeus vannamei di Probolinggo, Jawa Timur. Jurnal Ilmiah Perikanan dan Kelautan 10(1): 46-53.

Arsad, S., Ahmad, A., \& Atika, P, P. (2017). Studi Kegiatan Budidaya Pembesaran Udang Vaname (Litopenaeus vannameı) Dengan Penerapan Sistem Pemeliharaan Berbeda. 9 (1):1-14.

Aulia, D. (2018). Budidaya Udang Vaname. Jakarta Pusat: Amafrad Press.

BPS. (2016). Statistik Sumberdaya Laut Pesisir. Badan Pusat Statistik.

Budiardi, T., Batara, T., \& Wahjuningrum, D. (2005). Tingkat Konsumsi Oksigen Udang Vaname (Litopenaeus vannameI) dan Model Pengelolaan Oksigen Pada Tambak Intensif. Jurnal Akuakultur Indonesia 4 (1): 86-96.

Dahlan, J., Muhaimin, H., \& Agus, K. (2019). Pertumbuhan Udang Vaname (Litopenaeus vannameI) yang Dikultur pada Sistem Bioflok dengan Penambahan Probiotik. JSIPi Jurnal Sains dan Inovasi Perikanan). 1 (2):1-9.
DJPDS, (2020). Baseline Data Ekspor Udang 2019. Direktorat Jenderal Penguatan Daya Saing Produk Perikanan, Kementerian Kelautan dan Perikanan. Jakarta.

Elfidiah. (2016). Study Kasus Optimalisasi Tambak Udang Dari Pencemaran Amoniak $\left(\mathrm{NH}_{3}\right)$ Dengan Metode Bioremedasi. Distilasi 1 (1): 57-61.

Farchan, M. (2018). Pengelolaan Kawasan Budidaya Perikanan Berkelanjutan. Jakarta: Pusat Penelitian dan Penyuluhan Kelautan dan Perikanan. Gedung Mina Bahari.

Fuady, M, F., Mustofa N, S,.., \& Haerudin. (2013). Pengaruh Pengelolaan Kualitas Air Terhadap Tingkat Kelulushidupan Dan Laju Pertumbuhan Udang Vaname (Litopenaeus vannameI) Di Pt. Indokor Bangun Desa, Yogyakarta. Diponegoro Journal Of Maquares. 2 (4): 155-162.

Ghufron, M., Mirni, L., Putri, D., Wulan, S., \& Hari, S. (2018). Teknik Pembesaran Udang Vaname (Litopenaeus vannameI) Pada Tambak Pendampingan Pt Central Proteina Prima Tbk Di Desa Randutatah, Kecamatan Paiton, Probolinggo, Jawa Timur. Journal of Aquaculture and Fish Health. 7 (2): 70-77.

Haliman, R.W., \& D Adijaya. (2008). Udang Vanname. Jakarta: Penebar Swadaya.

Isamu, I., Idrus, S., \& Lukman, Y. (2018). Analisis Kelayakan Usaha Budidaya Udang Vaname Pola Tradisional Plus Di Kecamatan Samaturu Kabupaten Kolaka. Jurnal Sosio Agribisnis.3 (1).

Kasmir, \& Jakfar. (2016). Studi Kelayakan Bisnis. Jakarta: Prenamedia Group.

Mustafa, A., Irmawati, S., \& Mudian, P. (2010). Studi Penggunaan Produk Kimia Dan Biologi Pada Budidaya Udang Vaname (Litopenaeus vannameı) di Tambak Kabupaten Pesawaran Provinsi Lampung. J.Ris Akuakultur 5 (1): 115-33.

Primyastanto, Mimit. (2011). Feasibility Study Usaha Perikanan. UB Press.

Pulungan, R, H., Lily, F., \& Emalisa. (2015). Analisis Kelayakan Usaha Tambak Udang (Studi Kasus/ : Desa Sei Meran, Kec. Pangkalan Susu, Kab. Langkat).

Sawhney, S., \& Gandorta, R. (2010). Growth Response and Feed Conversion Efficiency of Tor putitora (Ham.) Fry at Varying Dietary Levels. Pakistan Journal of Nutrition. 9 (1): 86-90.

SNI. (2006). Produksi Udang Vaname (Litopenaeus vannamei) di Tambak Dengan Teknologi Intensif. Badan Standarisasi Nasional.

SNI. (2014). Produksi Udang Vaname (Litopenaeus vannamei Boone, 1931) Intensif di Tambak Lining. Badan Standarisasi Nasional. 
Sumardika, Putu. (2013). Kewirausahaan Perikanan. Jakarta: Bina Sumberdaya MIPA.

Ulumiah, M., Lamid, M., Soepranianondo,K., Al-Arif, M.A., Alamsjah, M.A., \& Soeharsono. (2020). Manajemen Pakan dan Analisis Usaha Budidaya Udang Vaname (Litopanaeus vannamer) pada Lokasi yang Berbeda di Kabupaten Bangkalan dan Kabupaten Sidoarjo. Journal of Aquaculture and Fish Health. 9 (2): 95-103.
Umar, H. (2005). Metode Penelitian Untuk Tesis Dan Bisnis. Jakarta: Grafindo Persada.

Ustiani, N. (2015). Pengaruh Struktur Modal, Kepemilikan Manajerial, Keputusan Investasi, Kebijakan Dividen, Keputusan Pendanaan Dan Profitabilitas Terhadap Nilai Perusahaan.

Witoko, P., Ninik, P., Nuning, M, N., Dwi, P., \& Epro, B. (2018). Budidaya Udang Vaname (Litopenaeus vannamer) di Keramba Jaring Apung Laut. 410-18. 